\title{
THE INFLUENCE OF PROBLEM-BASED LEARNING AND DIRECT TEACHING ON STUDENTS' LEARNING OUTCOMES
}

\author{
Heru Raharjo ${ }^{1}$, M. Khairudin ${ }^{2}$, Jamil Abd Baser ${ }^{3}$ \\ ${ }^{1}$ Department of Automotive Engineering, SMK N 1 Ngawen, Gunungkidul, Yogyakarta, Indonesia \\ ${ }^{2}$ Department of Electrical Engineering Education, Universitas Negeri Yogyakarta, Indonesia \\ ${ }^{3}$ Faculty of Technical and Vocational Education, Universitas Tun Hussein Onn Malaysia, Malaysia \\ E-mail: heru_pascauny@yahoo.co.id
}

\begin{abstract}
One of the student-centered learning methods which is able to improve the students' learning outcomes is Problem-Based Learning (PBL). This study examined (1) the difference in the learning results of students using PBL and Direct Teaching (DT) with high and low learning motivation and creativity, (2) the influence of learning methods with motivation and creativity toward learning outcomes, and (3) the difference in the learning results of students using PBL and DT in terms of learning motivation and creativity. The subject consisted of students of Vocational High Schools or Sekolah Menengah Kejuruan N 1 Ngawen. The data analysis used an ANOVA test and a T-test. The results revealed (1) insignificantly different learning outcomes between the use of PBL and DT, (2) insignificantly different learning outcomes with the significance of 0.652 between students with high and low motivation, (3) significantly different learning outcomes with the significance of 0.039 between students with high and low creativity, (4) influence of the interaction between learning methods with learning motivation to the learning outcomes, (5) influence of the interaction between learning methods with creativity to the learning outcomes, (6) insignificantly different learning outcomes between students using PBL and DT in terms of learning motivation, and (7) insignificantly different learning outcomes between students using PBL and DT in terms of creativity.
\end{abstract}

Keywords: problem-based learning, direct teaching, learning motivation, creativity

\section{INTRODUCTION}

Vocational High Schools also known as Sekolah Menengah Kejuruan (SMK) have the mission to educate middle-level labour candidates who have the capability in accordance with the required workforce. Vocational High School students should understand the work process, situation, and the work environment in which they will be working later on. The success of vocational education is not only measured by the student's academic performance in schools but also measured by the work achievement in the workforce after they graduate. Therefore, the curriculum developed in Vocational High School should follow the advancement and fulfill demands of the business and industrial world (Finch \& Crunkilton, 1999).

Vocational High Schools students are expected to have a high motivation to achieve learning success. The students are also expected to have creativity so that they will become creative and insightful toward their future. In fact, the students have diverse motivation and creativity. Then these differences require different treatments for each student.

SMK N 1 Ngawen Gunungkidul has already had data regarding the level of motivation and creativity which are derived from the entrance test results for new students, but the school has not optimized the data to be implemented in the process of teaching and learning. Even the students' learning outcomes for the productive lesson are still low. The exam results of the main competency on using measuring tools in the academic year of 2015/2016 reveal that there were many students who still had not reached the minimum completeness criterion also known as Kriteria Ketuntasan Minimal (KKM). Table of results of learning measuring tools based on the limits of the minimum completeness criterion can be seen in Table 1. Students who have not yet reached the score of criterion for minimum completeness should follow remedial tests. 
Implementation of the test indeed takes time and thoughts, and is good for the teachers as well as the school.

Table 1. Percentages of Test Results for Measuring Tool Competency

\begin{tabular}{ccc}
\hline Class & More than KKM & Less than KKM \\
\hline X OA & $37.5 \%$ & $62.5 \%$ \\
X OB & $43.75 \%$ & $56.25 \%$ \\
X OC & $28.125 \%$ & $71.875 \%$ \\
X OD & $37.5 \%$ & $62.5 \%$ \\
\hline
\end{tabular}

The results below the minimum completeness criterion were influenced by several factors, one of which was the learning method applied by the teachers. A learning method is a series of ways or strategies designed to create the conditions so that learning runs as expected, students can improve their activeness or involvement in the process of learning and yield a good learning (Joyce, et al., 2009; Haryanto \& Khairudin, 2012; Parkay \& Stanford, 2010)

Learning is considered to be effective if it applies the teaching and learning process which is able to increase students' learning activities and results in optimal learning outcomes. The effectivity of learning can be observed from students' abilities in applying the acquired knowledge (Guthrie \& Schuerman, 2011; Wong \& Wong, 2005).

One of the student-centered learning methods which is able to improve the results of student learning is problem-based learning (PBL). It is a method of learning which provides students with real problems so that students can enhance their knowledge and understanding through them (Liu, et al., 2009; Marsh, 2010; Baden \& Major, 2004).

Problem-based learning is not solely problem-solving. It deals with problems which are related to improving knowledge and understanding (Sari \& Mukhadis, 2017). This method offers active and progressive learning focusing on unstructured problems used as a starting point in the learning process. It is often carried out with a team approach emphasizing on skills building in line with decision making, discussion, team maintenance, conflict management, and team leadership.

Problem Based Learning is a method of learning that challenges students to learn by working with the group to find solutions to real problems and those issues are used to enhance the sense of curiosity, critical ability and analysis upon the subject matter.

Steps of Problem-Based Learning begin with the discovery of a problem that is designed by the teacher then students perform the learning activities by seeking information from a variety of sources, group discussions, practicing the investigation in order to find the problems as well as the solution so that through the process, the students can find new knowledge. Syntax of Problem Based learning consists of 5 phases, namely: (1) providing orientation of problems, (2) organizing students for study, (3) assisting independent and group investigation, (4) developing and presenting artifacts, and (5) analyzing and evaluating the process of problem-solving (Arends, 2008; Suprijono, 2010; Tan, 2003; Febriana, 2017).

In the other hand, a Direct Teaching method is a type of learning applied by teacher to transfer experience and information to students by delivering explanation in the first place, definitions, principles, and concepts of learning materials as well as providing exercises in the forms of lectures, assignments, discussions, and questions and answers from the learning materials (Marsh, 2010; Parkay \& Stanford, 2010). The direct teaching method is characterized as (1) teacher-centered, (2) teacher attendance, (3) students receive teacher explanation, (4) learning goals are stated in the beginning of the course, (5) suitable for basic development materials, and (6) unsuitable for unstructured materials.

Learning motivation is a change of energy in students' inner selves which encourages them to do the things to achieve something that makes the students still want to 
do it and complete the academic assignments (Mc Lean, 2009; (Woolfolk, 2007; Galton, et al., 2009).

Indicators to measure the learning motivation expressed by Sardiman (2011) include: (1) persistence in learning, (2) the resilient in the face of difficulties, (3) interest in learning, (4) the desire to succeed in learning, (5) self study, and (6) awards.

Students' creativity is indispensable in the process of learning. Creativity is a mental process to provide a solution to the existing problem, to give you an idea, concept or to create a product that provides solutions to overcome the problems (Carter, 2007; Lau, 2011; Adair, 2007). Another definition of creativity according to Munandar (2002) is the ability to create something new, as the ability to give new ideas that can be applied in problemsolving, or as the ability to see new relationships among the elements that already existed before.

Students who have high creativity will stand out in learning. Students with creativity have the following characteristics: (1) high curiosity, (2) learn with full responsibility, (3) make a decision carefully, (4) is eager to problem-solving, and (5) is insightful.

When teaching and learning process pays attention to motivation, creativity and is supported by appropriate learning methods, it will yield optimal learning results. Ranjan \& Rahman stated that the results of learning according to Bloom are divided into three domains namely affective cognitive, and psychomotor which are related to attitudes, knowledge, and personal skills respectively. The learning outcomes tests used in this study include cognitive and psychomotor tests.

The PBL learning method is studentcentered. The students discover knowledge by constructing their own knowledge. While Direct Teaching method is teacher-centered. The knowledge that is formed is temporary. Students who have high motivation will always be passionate and enthusiastic about the teaching and learning process whereas students with low motivation do not have a passion for learning that may lead to low results of learning. Similarly, students with high creativity will always be actively involved to solve the learning problems than students who have low creativity.

This study aims to find out: (1) the difference between the learning outcomes of students with high and low motivation and creativity who are taught with Problem Based Learning and Direct Teaching (2) the influence of the interaction between the learning method with learning motivation and creativity toward the learning results, and (3) the difference in learning outcomes of students who learn with PBL and Direct Teaching in terms of motivation and creativity.

\section{METHOD}

This study was carried out in a quasi experiment with a factorial design by giving treatments of problem-based learning and direct teaching. It was conducted in SMK Negeri 1 Ngawen Gunung Kidul Yogyakarta, which is located in Ngawen, Gunungkidul, Yogyakarta, Indonesia. The subject of this study consisted of grade $\mathrm{X}$ students in the Department of Light Vehicle Engineering which consisted of class $\mathrm{XOA}$ and class XOB. Class XOA was taught through PBL while class $\mathrm{XOB}$ was taught through DT.

This study involved one experimental group and one control group which used PBL and DT respectively. Prior to the treatment, measurements of student motivation and creativity were conducted using motivation questionnaires and creativity tests. A pretest was conducted before the treatments. To examine the students' learning outcomes, a posttest was conducted after the treatments. The operational design of this study is presented in Table 2. 
Table 2. Operational Design

\begin{tabular}{cccc}
\hline Group & Pretest & Treatment & Posttest \\
\hline Experiment & $\mathrm{O}_{1}$ & $\mathrm{X}_{1}$ & $\mathrm{O}_{2}$ \\
Control & $\mathrm{O}_{1}$ & $\mathrm{X}_{2}$ & $\mathrm{O}_{2}$ \\
\hline
\end{tabular}

Where

EG : Experiment Group

CG : Control Group

$\mathrm{O}_{1}$ : Pretest, questionnaire on learning motivation, creativity test

$\mathrm{O}_{2}$ : Posttest

$\mathrm{X}_{1}$ : PBL method

$\mathrm{X}_{2}$ : Direct Teaching method

Data collection techniques in this study used: (1) a learning motivation questionnaire to determine the level of students' learning motivation, (2) a learning result test consisting of a theoretical test and a competency practical test using measurement tools. The theoretical test is a description test on mechanical measurement tool materials while the practical test is a performance test of how to use mechanical measurement tools to measure automotive components, and (3) creativity test which is a standardized verbal creativity test. The data analysis techniques were (1) a homogeneity test for initial abilities, (2) a descriptive statistic test, (3) a requirement analysis test, (4) a hypothesis test with threeway ANOVA, and (5) a T-test.

\section{RESULTS AND DISCUSSION}

The homogeneity test of the initial ability was conducted to examine if the groups had the same condition or not, in other words the variance came from a homogeneous population or not. The results can be seen in Table 3 .

Table 3. The Homogeneity Test Results of Initial Ability

\begin{tabular}{cccc}
\hline Data & $\mathrm{F}_{\text {value }}$ & Sig. & Information \\
\hline Pretest & 0.051 & 0.882 & Homogen \\
\hline
\end{tabular}

Before conducting the hypothesis testing, a testing requirements analysis was done including the normality test and the homogeneity test. The results of the testing requirements test can be seen in Table 4 .
Table 4. Results of Testing Requirements Analysis

\begin{tabular}{ll}
\hline \multicolumn{1}{c}{ Data } & \multicolumn{1}{c}{ Information } \\
\hline Learning Outcome & Normal and Homogen \\
Motivation & Normal and Homogen \\
Creativity & Normal and Homogen \\
\hline
\end{tabular}

Hypothesis testing is done using an ANOVA test with three-way factorial and a Ttest. The summary of hypothesis testing can be seen in Table 5 .

Table 5. Summary of Hypothesis Testing

\begin{tabular}{ccl}
\hline Data & Sig. & \multicolumn{1}{c}{ Information } \\
\hline PBL x DT & 0.000 & difference \\
HM x LM & 0.652 & no difference \\
HC x LC & 0.039 & difference \\
\hline
\end{tabular}

Where

PBL : Problem-Based Learning

DT : Direct Teaching

HM : High Motivation

LM : Low Motivation

HC : High Creativity

LC : Low Creativity

In addition, the summary of the result of the interaction test using Anava and the calculation of the T-test are presented in Table 6 and Table 7.

Table 6. Summary of the Interaction Test

\begin{tabular}{lcc}
\hline \multicolumn{1}{c}{ Data } & Sig. & Information \\
\hline Method*Motivation & 0.000 & Interaction \\
Method*Creativity & 0.015 & Interaction \\
\hline
\end{tabular}

Table 7. Summary of T-Test

\begin{tabular}{lcl}
\hline \multicolumn{1}{c}{ Data } & Sig. & \multicolumn{1}{c}{ Information } \\
\hline PBLLM x DTLM & 0.000 & Difference \\
PBLHM x DTHM & 0.126 & No Difference \\
PBLLC x DTLC & 0.000 & Difference \\
PBLHC x DTHC & 0.109 & No Difference \\
\hline
\end{tabular}

Where

PBLLM : PBL Low Motivation

DTLM : DT Low Motivation

PBLHM : PBL High Motivation

DTHM : DT High Motivation

PBLLC : PBL Low Creativity

DTLC : DT Low Creativity

PBLHC : PBL High Creativity

DTHC : DT High Creativity

The results of the first hypothesis testing noted that there was a significant difference with the significance of 0.000 in the results of 
the learning measurement tools among the students who were taught by PBL and direct teaching methods. Data from the results of learning measurement tools of the students taught with PBL gained an average score of 78.42 which was higher compared to those taught by direct teaching method with an average score of 74.07. This implies that the application of the PBL method has better influences on the results of the learning competence of measurement tools compared to the direct teaching method.

PBL focuses on the students' activities grounded on a constructivist view in which students construct their knowledge by meaningful learning. The activities offered by PBL begin with orientation on the issue and then students are required to answer the problems. Students are required to actively read, seek information from the internet or books, having discussions with friends and practice on real objects either independently or groups. Students not only practice when reading the given job sheet, but the students analyze the first problem that arises then look for alternatives to solve the problem so that learning run more effective and meaningful.

Students reconstruct knowledge independently during the learning process. The PBL learning also requires group works and discussions followed by a presentation of findings when conducting an inquiry, in which the students will help each other in mastering the lesson. Students will ask questions in their own language without any hesitation. A smart student will feel appreciated, given the opportunity to guide his friends, while the students with low abilities will be more likely to ask their friends who know better without any hesitation. This will certainly motivate the students to produce better learning outcome. PBL is able to increase the activity, attention and cooperation among students. The teacher's domination decreases while the active role of the students increases. The high activity and attention of students will improve their abilities to explore the lessons. Students will be more active to seek information as issues of a problem and discussions. They learn to seek information from various sources such as from the internet, reference books, vehicle manuals, or ask the teacher. Participation and cooperation will streamline the process of elaboration in learning. Elaboration is the process of strengthening and deepening the mastery of the subject matter. Consequently, students will give and receive information so that the materials will be more complete.

This method can stimulate motivation during the learning which is ultimately able to improve the students' learning outcomes. When learning was taking place, students who were taught by Problem Based Learning were enthusiastic. They were active to learn and the classroom seemed rowdy in positive ways because they gave arguments upon the subject matter and solved the problem. They were also very serious during the activities, from the beginning to the end, and utilized the time effectively. While, with Direct Teaching method, the students pay serious attention only at the beginning of the learning practice, only relied on the existing instructions in the job sheet without proposing any innovation which was more effective. After the practical data was obtained, they tended to be passive as they assumed the practice was over, without analyzing the data. This indicates that Direct Method is only suitable for simple and structured materials but does not match for complex, analytical and problem-solving materials.

The second hypothesis testing revealed that there was no a significant difference with the significance of 0.652 in the results of learning measurement tools among students with high and low motivation. The students with high motivation achieved higher learning outcomes than those with low motivation. The students with high and low learning motivation obtained the average scores of 76.60 and 75.70 respectively.

Theoretically, students with high learning motivation will get higher learning results. 
They will obtain better learning results compared to students with low learning motivation. The test results showed an increase in learning outcomes among students with both high and low learning motivation. The students with low learning motivation gained the average scores of 39.26 and 75.70 in the pretest and the posttest respectively. The students with high learning motivation got the average score of 39.81 and 76.60 in the pretest and the posttest respectively.

Although this study showed that there existed an increase of learning outcomes among students who have high and low learning motivation, but there was no a significant difference between the learning results on learning measurement tools among students with high and low learning motivation. This indicated there were other factors that influence the learning outcomes. These factors were the learning methods, Problem Based Learning and Direct Teaching.

The third hypothesis testing indicated that there were significant differences with the significance of 0.039 in the learning outcomes of measurement tools between students with high and low creativity. Students with high creativity had better learning results than those with low creativity. The results of the data analysis indicated that the group of students with high and low creativity had an average score of 77.06 and 75.28 respectively.

The test results also noted that creativity factor was proved to have significant influence in serving to improve the learning results of measurement tools. Someone who has creativity tries to find something new, or modifies the existing things to be more useful. Desires to develop or explore potentials drive students to utilize their creativity knowing new things. These conditions give significant effects to the learning results.

Every student has different levels of creativity. Students who have a high creativity tend to have a high curiosity, study with confidence, be able to make decisions carefully, be pleased towards problem-solving, be insightful (divergent thinking), have many alternatives in facing problems, and have a strong belief to the success of their learning. A strong belief and confidence towards the success of learning lie as a foundation for students in reaching the better results.

Students with low creativity tend to be capable of seeing problem and information clearly, linearly minded, easily give up, lack confidence and have no strong convictions, do not have the courage to take risks, and can not make decisions. With these ways of thinking, students are not accustomed to thinking of finding many alternatives in understanding every problem they face, have low curiosity and lack of confidence, so that if a valid alternative is applied in the practice of understanding the problem and the solution are not successful, consequently the students feel hopeless. Students tend to have a textual curiosity, thinking according to the situation and condition of the problems encountered. These conditions greatly affect the achievement of learning outcomes. Students with low creativity tend to have less optimal learning outcomes.

The fourth hypothesis testing shows an influence in the interaction of learning methods and learning motivation towards the results of learning Measurement Tools. This reveals that learning outcome is not only affected by methods used by the teacher but also by students' motivation to learn. The motivation affects the effectiveness of the implementation of learning methods which are student-centered.

Problem Based Learning method is a method of learning that demands student activeness in the learning process through a series of learning activities and practices. Students are organized in cooperative groups from a variety of different backgrounds. This heterogeneous groups then work together collaboratively to find problems and solve the problems together. Students read, search for information through the internet, training manual, discuss, investigate, practice the measurement on the automotive components, and the results of the discovery and the problem 
solving are then presented in front of the class. These conditions demand the students have a high learning motivation so that learning can run properly.

The description above can be concluded that both learning method and learning motivation have the same effect on the learning outcomes for the competency of using measurement tools. For that reasons, in the application of learning in the class teachers need to pay attention to student learning motivation. Teachers should be able to generate student motivation so that learning can take place effectively which in turn can improve student learning outcomes.

The fifth hypothesis testing showed an interaction between learning methods and student creativity on the results of learning measuring tools. It reveals that learning outcomes are not only influenced by learning method but also students' creativity. The creativity affects the effectiveness of learning method application especially the one to facilitate students to learn through discovery activities, problem analysis, investigation, presentation and reflection, as well as the process of integration and evaluation. Such conditions are essentials in the implementation of the PBL method. PBL facilitates students to learn through discovery activity, analysis problem, investigate to overcome the problem, perform presentation and reflection, and carry out the process of integration and evaluation.

The results of this study support the previous studies that conclude PBL concerns more on active student involvements in the learning (Tan, 2003; Arends, 2008; Liu, et al., 2009). In the practice, a teacher provides problem orientation, organizes the study, assists independent and group investigation, presents artefacts, analyzes and evaluates the process of problem-solving. The implementation of PBL learning method requires student ability to see problems, information, and data thoroughly and requires divergent thinking in terms of creativity so that they acquire knowledge and experience comprehensively. Students' creativity in understanding problems, finding information, and giving solutions in the learning process greatly affects the level of learning achievements.

Some factors affecting the occurring of interaction between learning methods (PBL and direct teaching) and the student level of creativity are explained as follows: (1) steps of PBL implementation provide wide opportunities for students to have high creativity to master the learning materials. The steps consist of teacher explains the learning procedure and offers problems to students, students collect data by doing experiments to seek for explanation and solution, students make research evidence to present and draw the conclusion from the results together with the teacher. Those steps oblige the students to actively participate, (2) the learning process of PBL requires students to learn collaboratively to find problems, search for information, and find solution related to the learning materials. Students must think critically and creatively. These lead them with high creativity to figure out numerous problem solving alternatives as the answers of problems proposed, and (3) the materials on the competence of using measuring tools, covering a number of materials such as basic knowledge, measuring results reading, practice of using measuring tools, and measuring results analysis, need student thinking creativity. Students should be responsive to solve the facing problems, both theoretical and practical questions.

Learning evaluation in this study was done in the form of theoretical and practical tests. The theoretical test was designed as essays so that students needed to be more creative in expressing their ideas with the knowledge constructed during the learning process. The practical test also required students' creativity that is conceptual understanding about the materials and not only memorizing them.

The sixth hypothesis test results revealed an insignificant difference in learning outcomes 
in the competency of using measurement tools between students who were taught with PBL and Direct Teaching in terms of low learning motivation. Students with low learning motivation had better results if taught with PBL than Direct Teaching methods. This indicated that the students with low learning motivation will achieve more effective results if taught with PBL.

The sixth hypothesis testing shows an insignificant difference with the significance of 0.126 in learning outcomes in the competence of using measurement tools between students who were taught using PBL and Direct Teaching in terms of high learning motivation. Ones with high motivation have good learning outcomes whether they are taught using PBL or Direct Teaching. In other words, the students with high motivation resulted in more effective results with PBL or Direct Teaching learning method.

Students with high motivation will be more enthusiastic in the learning process. They are characterized as: (1) diligent completing tasks, (2) perseverance in coping difficulties, (3) showing interests in various problems, (4) independent learning, (5) keen on variative activities, (6) expressing arguments and never give up, (7) never give up, and (8) like problem solving.

The characteristics above strongly support the application of PBL learning method that demands students to construct their own knowledge by solving problems to increase knowledge and understanding on the subject matter. PBL learning method can enhance student learning motivation during the learning process, because in this method teachers design the lesson with problems close to the real world of students and students should be actively involved in solving those problems. Students are organized in cooperative groups from a variety of different backgrounds of academic, motivation, creativity, family, etc.. This heterogeneous groups then work collaboratively to find problems and solve the problems together. Students read, search for information through internet, training manual, discuss, investigate, practice the measurement on the automotive components, and the results of the discovery and the problem solving are then presented in front of the class. Students with low ability and motivation will be driven to achieve the best results. Problem Based Learning as seen from those conditions is appropriate to be applied to students who have both high and low motivation.

The seventh hypothesis testing showed an insignificant difference with the significance of 0.109 in learning results of measurement tools between students taught with PBL and direct teaching in terms of high creativity. Students with high creativity had good learning results by being taught both by PBL or direct teaching. It meant that students with high creativity gained more effective results when taught by PBL or Direct Teaching methods.

Positive characteristics possessed by students with high creativity support the application of PBL. Measurement tool materials which are taught using PBL require critical, solutive, and creative thinking in solving problems. PBL is effectively applied both to students with high or low creativity. Students who have a high creativity will certainly yield good learning results due to it becomes the learning demands in PBL. While students who have low creativity are also more effectively taught with PBL rather than direct teaching since they will carry over the effects of PBL that demands students to discover, think critically, creatively and to be persistent to achieve the learning objectives.

\section{CONCLUSION}

In conclusion, this study suggests (1) a significant difference between the learning outcomes of students taught with Problem Based Learning and Direct Teaching. The learning results of students taught with PBL are higher compared with those taught with Direct Teaching and they differ significantly, (2) insignificant difference between the learning 
outcomes of students with high and low learning motivation. The learning outcomes of students with high motivation are better than the students with low learning motivation, but the difference is not significant; (3) a significant difference in learning outcomes between students with high and low creativity. Students with high creativity have better learning outcomes than those with low creativity and the results are significantly different, (4) a significant difference in learning outcomes between students taught by PBL and Direct Teaching in terms of low learning motivation. There is not a significant difference in student learning outcomes taught by PBL and direct teaching in terms of high learning motivation. Students with low learning motivation are better taught by PBL method, while students who have high learning motivation can be taught by both PBL or Direct Teaching, (5) a significant difference in the learning outcomes between students taught by PBL and Direct Teaching method in terms of low creativity. There is no a difference in the learning outcomes between students taught by PBL and Direct Teaching methods in terms of high creativity. Students with low creativity are better taught with PBL, whereas to teach students who have high creativity teachers can apply PBL or Direct Teaching method.

\section{REFERENCES}

Adair, J. 2007. The Art of Creative Thinking. How to Be Innovative and Develop Great Ideas. London and Philadelphia: Kogan Page

Arends, R.I. 2008. Learning to Teach, Belajar untuk Mengajar ( $7^{\text {th }}$ ed.). Translator: Helly Prayitno S \& Sri Mulyantini S. New York: McGraw Hill Companies

Baden, M.S. \& Major, C. H. 2004. Fondation of Problem-Based Learning. New York: McGraw-Hill

Carter, P. 2007. IQ and Personality Test. London and Philadelphia: Kogan Page
Finch, C. R. \& Crunkilton, J. R. 1999. Curriculum Development in Vocational and Technical Education: Planning, Content, and Implementation ( $5^{\text {th }}$ ed.). Boston: Allyn and Bacon, Inc.

Galton, M., Steward, S., Hargreaves, L., Page, C. \& Pell, T. 2009. Motivating Your Secondary Class. Los Angeles: Sage Publication

Guthrie, J.W. \& Schuermann, P.J. 2011. Leading Schools to Succes: Constructing and Sustaining High Performing Learning Culture. Los Angeles: SAGE Publication, Inc.

Haryanto \& Khairudin, M. 2012. Pengembangan Model Pembelajaran Jaringan Syaraf Tiruan Tipe Supervised Learning sebagai Media Pembelajaran. Jurnal Pendidikan Teknologi dan Kejuruan. 21.1, 83-89

Joyce, B., Weil, M. \& Calhoun, E. 2009. Model of Teaching. Boston: Prentice Hall

Lau, J. Y. F. 2011. An Introduction to Critical Thinking and Creativity. Think More, Think Better. Hoboken: John Wiley \& Son, Inc.

Liu, W. C., Liau, A. K., \& Tan, O. S. 2009. EPortofolios for Problem-Based Learning: Scaffolding Thinking and Learning in Preservice Teacher Education. In Tan, O.S. (Ed.). Problem-Based Learning and Creativity. Singapore: Cengage Learning Asia Pte Ltd.

Marsh, C. J. 2010. Becoming a Teacher: Knowledge, Skills and Issues. (5th ed.). French Forest: Pearson Australia

McLean, A. 2009. Motivating Every Learner. Los Angeles: Sage Publication

Munandar, U. S. C. 2002. Kreativitas \& Keberbakatan. Strategi Mewujudkan Potensi Kreatif \& Bakat. Jakarta: PT Gramedia Pustaka Utama

Parkay, F.A. \& Stanford, B.H. 2010. Becoming a Teacher, $\left(8^{\text {th }}\right.$ ed.). Upper Saddle River: Pearson Education, Inc. 
Ranjan, N. \& Rahman, N. (n.d.) Role of Teacher in Enhacncing Learning Achievement of Child \& Emphasis on Teacher Skill Development, Knowledge Building and ICT.

Febriana, Rina. 2017. The Effectiveness of Project Based Learning on Students' Social Attitude and Learning Outcomes'. Jurnal Pendidikan Teknologi dan Kejuruan.23.4, 374-382

Sardiman, A. M. 2011. Interaksi dan Motivasi Belajar Mengajar. Jakarta: PT. Raja Grafinddo Persada

Suprijono. 2010. Cooperative Learning, Teori dan Aplikasi PAIKEM. Yogyakarta: Pustaka Pelajar.
Tan, O. S. 2003. Problem-Based Learning Innovation, Using Problems to Power Learning in the $21^{\text {st }}$ Century. Singapore: Cengage Learning Asia Pte Ltd.

Sari, V.P.E. \& Mukhadis, A. 2017. The Effect of Problem Based Learning with Gallery Project and Locus of Control on Learning Achievement. Jurnal Pendidikan Teknologi dan Kejuruan. 23. 4, 392-401

Wong, H. K. \& Wong, R. T. 2005. How to be An Effective Teacher: the First Days of School. Montain View: Harry K. Wong Publication, Inc.

Woolfolk, A. 2007. Educational Psychology. Boston: Pearson Education, Inc. 